\title{
Peran Gereja dalam Pembinaan Kerohanian Remaja di Gereja Pantekosta di Indonesia Kota Palangkaraya
}

\author{
Bambang Sriyanto, Thomy Sanggam Hasiholan Sihite \\ Sekolah Tinggi Teologi Efata, Salatiga, Jawa Tengah \\ bezuhlel@gmail.com
}

\begin{abstract}
The general perception is that teenagers are a group of people who are often a bother to parents. The role of the church is very important to the formation of members of the congregation, including youth, both in worship, fellowship and service. The church environment must be a pleasant environment for adolescents, because if adolescents leave the church for various reasons, it becomes increasingly difficult to conduct spiritual formation to this group. This study uses a qualitative descriptive method by involving adolescents as respondents to find out how adolescents think about the role of the church in their spiritual formation, so that by getting data from adolescents, it can produce data analysis about whether the church has done its work and how the church can continue to conduct adolescent spiritual guidance. well. In conclusion, the church must continue to learn about what it likes, likes, and interests of adolescents, so that it can create an atmosphere and environment that brings, and invites them to love worship. Youth are accepted into fellowship in the church, get good service, so that they become part of the ministry, and can serve with responsibility.
\end{abstract}

Keywords: GPdI Palangkaraya; youth spirituality; youth coaching; the role of the church

\begin{abstract}
Abstrak
Persepsi umum berpendapat bahwa remaja adalah kelompok orang-orang yang sering menyusahkan orang tua. Peran gereja sangat penting terhadap pembinaan warga jemaatnya, termasuk remaja, baik dalam ibadah, persekutuan dan pelayanan. Lingkungan gereja haruslah menjadi lingkungan yang menyenangkan untuk remaja, karena apabila remaja meninggalkan gereja oleh berbagai alasan, maka semakin sulit untuk melakukan pembinaan secara rohani kepada kelompok ini. Penelitian ini menggunakan metode deskriftif kualitatif dengan melibatkan remaja sebagai responden untuk mengetahui begaimana pendapat remaja tentang peranan gereja terhadap pembinaan kerohanian mereka, sehingga dengan didapatkannya data dari remaja maka dapat menghasilkan analisa data tentang apakah gereja sudah melakukan tugasnya dan bagaimana gereja dapat terus melakukan pembinaan kerohanian remaja dengan baik. Kesimpulannya, gereja harus terus mempelajari tentang apa yang disukai, digemari, diminati remaja, sehingga dapat menciptakan suasana dan lingkungan yang membawa, serta mengajak mereka mencintai ibadah. Remaja diterima dalam persekutuan di gereja, mendapatkan pelayanan yang baik, sehingga mereka menjadi bagian dalam pelayanan, dan dapat melayani dengan tanggung jawab.
\end{abstract}

Kata Kunci: GPdI Palangkaraya; kerohanian remaja; pembinaan remaja; peran gereja 


\section{PENDAHULUAN}

Remaja sangat erat kaitan-nya dengan pertumbuhan baik secara fisik, mental maupun rohani. Masa remaja merupakan masa yang amat penting dan mentukan bagi perkembangan kerohanian seseorang. Di era teknologi dan ilmu pengetahuan perkembangan pesat, remaja juga harus berada dalam kancah kehidupan dalam dunianya dan harus berbaur dengan orang lain dengan berbagai problematikanya, oleh karena itu, selain remaja berhadapan dengan problem dari dalam dirinya sendiri, hal-hal diluar dirinya pun misalnya lingkungan keluarga, pergaulan, tayangan-tayangan dan tontonan dari televisi, internet, dan lingkungan lain lebih luas, akan sangat mempengaruhi situasi dan kondisi remaja secara psikis dan mental. Orang tua atau keluargalah yang diharapkan dapat menjadi kunci dalam mendidik anak remaja, dan orang tuapun kadang-kadang dalam kesibukan dimasa sekarang, memandang sekolah (guru) dan gereja sebagai institusi yang diharapkan menjadi pembimbing dan pembina kerohanian bagi remaja.

Salah seorang pakar psikologi perkembangan Elizabeth B. Hurlock menyatakan bahwa masa remaja ini dimulai pada saat anak mulai matang secara seksual dan berakhir pada saat ia mencapai usia dewasa secara hukum masa remaja terbagi menjadi dua yaitu masa remaja awal dan masa remaja akhir. ${ }^{1}$ Masa remaja awal dimulai pada saat anak-anak mulai matang secara seksual yaitu pada usia 13 sampai 17 tahun, sedangkan masa remaja akhir meliputi periode setelahnya sampai dengan sembilanbelas tahun, yaitu usi dimana seorang dinyatakan dewasa secara hukum. Tuhan Yesus, pada masa pelayanan-Nya dimuka bumipun memberikan perhatian dan pelayanan kepada tiap orang, laki-laki perempuan, dari berbagai tingkatan umur. Dalam Markus 5:41-42, Yesus memegang tangan anak perempuan Yairus, yang berumur 12 tahun, umur menuju remaja dan membangunkan dia dari kematian. Ini adalah salah satu bentuk pelayanan Tuhan kepada begitu banyak orang di Alkitab, termasuk juga remaja.

Cerita Alkitab yang seringkali disampaikan kepada anak-anak sekolah minggu tentang Eutikus, seorang muda dari Troas yang mengantuk dan terjatuh dari jendela tingkat atas, sewaktu Paulus berbicara sangat lama disana (Kis. 20:7-12), dan tanpa bermaksud mengabaikan mujizat yang dilakukan Tuhan melalui Paulus, cerita ini menunjukan salah satu problem "kecil" orang muda yang merupakan bagiaan dari jemaat gereja yang sedang berkembang dimasa itu, bagaimana orang muda dalam kategori remaja, karena berada ditempat yang benar, tetapi duduk ditempat yang tidak lazim (walaupun mungkin dirasakannya sebagai tempat yang nyaman untuknya). Ini salah satu gambaran bagaimana remaja di segala masa seringkali menjadi bagiaan yang dianggap selalu salah dalam bertingkah, belum sepenuhnya dapat mengatur hidupnya, selanjutnya tidak diperhatikan

${ }^{1}$ Elizabeth B Hurlock, Psikologi Perkembangan, Suatu pendekatan sepanjang Rentang Kehidupan (Jakarta: Erlangga, 1999), 206. 
dengan baik oleh orang dewasa disekitarnya, sehingga disituasi ini seringkali mengakibatkan sesuatu hal yang fatal untuk remaja tersebut bahkan juga orang-orang yang ada di sekelingnya.

Oleh sebab itu, maka gereja sebagai persentasi Tuhan Yesus diharapkan oleh umat, bahkan oleh dunia untuk dapat menjadi bagian yang penting dalam pembinaan kerohanian remaja, khususnya remaja Kristen. Adalah tantangan bagi gereja untuk berperang seta menghadapi remaja dengan kebutuhan perkembangan jasmani terutama kebutuhan rohani remaja sebagai bagiaan dari umat dengan berbagai aspek kehidupan. Di lingkungan Gereja Pantekosta di Indonesia kota Palangka Raya melihat kenyataan bahwa banyak sekali anakanak sekolah Mingu yang diantar orang tuanya untuk ibadah sekolah Minggu, tetapi setelah remaja, mereka jarang bahkan tidak muncul lagi untuk ikut ibadah karena berbagai alasan. Dalam usia remaja, kegiatan pribadi, kegiatan sekolah seperti kegiatan ekstra kurikuler, kegiatan pertemanan akan lebih meningkat, bahkan ada remaja yang harus bekerja sebelum waktunya untuk membantu orang tua mencari nafkah; itu alasan yang umum dan banyak alasan lain yang diberikan oleh orang tua, atau remaja itu sendiri yang menurut mereka sangat permisif tentang ketidakhadiran mereka di berbagai kegiatan gereja.

Penelitian yang dilakukan oleh Santy Sahartian menunjukkan bahwa ada pengaruh dari pembinaan rohani gereja terhadap gaya hidup konsumerisme pemuda Gereja Pantekosta di Indonesia Theofilus Blitar. ${ }^{2}$ Penelitian pada tempat yang berbeda juga menunjukkan bahwa ada pengaruh pembinaan rohani di keluarga terhadap karakter pemuda di Gereja Bethel Apostolik dan Profetik Bunga Bakung Surakarta. ${ }^{3}$ Generasi muda merupakan bonus demografi di Indonesia pada tahun 2020 hingga 2040, mereka adalah kelompok produktif yang perlu mendapatkan pelayanan secara maksimal dari gereja. ${ }^{4}$ Mempersiapkan generasi muda untuk masa depan yang lebih baik, dengan memberikan pendidikan yang baik, menambah keterampilan dan kepandaian melalui berbagi kursus dan latihan, baik pelajaran sekolah, kegiatan fisik dan olahraga, atau kesenian, adalah hal yang wajar dilakukan oleh orang tua atau remaja yang bersangkutan, tetapi adalah hal yang penting bagi remaja itu sendiri, bahwa mereka pun harus diperlengakapi dengan kebutuhan rohani yang memadai sebagai bekal mereka menjalani kehidupan mereka pada masa mudanya dimasa yang akan datang. Karena akan tiba waktunya remaja harus memutuskan sendiri dan membuat pilihanya sendiri dalam kehidupanya sekarang dan yang akan datang. Oleh karena itu sudah

\footnotetext{
${ }^{2}$ Santy Sahartian, "Pengaruh Pembinaan Rohani Gereja Berdasarkan Efesus 4:17-24 Terhadap Gaya Hidup Konsumerisme Pemuda Gereja Pantekosta di Indonesia Theofilus Blitar” Jurnal Teologi Berita Hidup 1 no. 1 (2018): 31-45.

${ }^{3}$ Santy Sahartian, "Pengaruh Pembinaan Rohani Di Keluarga Terhadap Karakter Pemuda Berdasarkan Kolose 2: 6-10" Fidei: Jurnal Teologia Sistematika dan Praktika 2 no. 1 (2019): 20-39.

${ }^{4}$ Rahmat Kristiono, "Bonus Demografi Sebagai Peluang Pelayanan Misi Gereja di Kalangan MudaMudi” Jurnal Teologi Berita Hidup 1 no. 2 (2019): 174-182.
} 
seharusnya firman Tuhan yang diberikan kepada anak-anak diharapkan berlanjut terus agar pengajaran tidak mengalami stagnasi. ${ }^{5}$

James Dobson menyatakan bahwa menjadi dewasa bukanlah suatu yang terjadi dalam seketika; remaja, setelah mengalami pubertas apabila tidak berhati-hati, dapat terperosok ke dalam jurang kegelapan, di mana kebanyakan remaja terjerumus ke dalamnya, dalam perjalanan mereka menuju kedewasaan. ${ }^{6}$ Oleh karena itu Dobson menyarankan kepada remaja untuk mencari sahabat dalam menghadapi masalahnya, dan untuk menyiapkan diri memperbaiki keadaanya ia haruslah orang dewasa yang mengerti masalah anak muda dan salah satu yang disarankan kepada remaja sebagai sahabatnya selain oran tua dan guru pembimbing, adalah pendeta. ${ }^{7}$

Menurut Tedd Tripp, selama 25 tahun pengalamanya didalam bidang administrasi sekolah, membesarkan anak, pelayanan pengembalaan serta konseling menyatakan bahwa, jarang ada anak yang lari dari rumah dimana kebutuhan mereka dipenuhi. Siapakh yang ingin meningalkan hubungan dalah hal mana ia merasa dikasihi dan dihargai? Anak macam apakah yang lari dari seseorang yang memahami dia, yang memahami Allah dan jalanjalan-Nya, yang memahami dunia ini serta bagaimana kerjanya, bahkan yang mempunyai komitmen membantu dia agar sukses? Bahwa anak-anak pada umunya tidak menolak kewibawaan yang benar-benar penuh kasih serta tidak mennetukan diri sendiri. ${ }^{8}$ Untuk itu gereja tidak hanya berupaya agar remaja tetap hadir, sementara gereja tidak memiliki kiatkiat yang baik untuk mengajak kaum muda mengerti tentang keperluan dan ketergantungan mereka kepada Tuhan terutama dimasa muda dan bahwa Tuhan cinta kepada orang muda, bahwa hal tersebut harus menjadi kesukaan mereka, harus tercermin dalam suasana dan kondisi gereja dalam berbagai pertemuan ibadahnya dimana remaja/kaum muda ikut hadir di dalamnya.

\section{Kerangka Berpikir}

Ada kerangka berpikir dalam penelitian ini. Pertama, peran gereja melalui ibadah yaitu mendorong para remaja untuk beribadah dengan setia. Melalui ibadah remaja dapat mengekspresikan diri dan menghormati Tuhan. Para remaja menerima firman untuk memperlengkapi diri mereka. Kedua, peran gereja melalui persekutuan yaitu mendorong para remaja aktif dalam persekutuan sesama remaja gereja. Persekutuan digereja diharapkan sebagai sarana mengembangkan diri secara positif, sehingga menjauhkan mereka dari pergaulan negatif. Peran gereja melalui pelayanan yaitu mendorong remaja

${ }^{5}$ Iris V Cully, Dinamika Pendidikan Kristen (Jakarta: BPK Gunung Mulia,1985), 5.

${ }^{6}$ James, Dobson, Menjelang Masa Remaja (Jakarta: BPK Gunung Mulia, 1986), 11.

${ }^{7}$ Ibid., 29.

${ }^{8}$ Tedd, Tripp.,Shepperding a Child's Heart, Menggembalakan Anak Anda (Malang: Gandum Mas, 2002). 
terlibat dalam pelayanan, berkomitmen, disiplin dan bertanggungjawab terhadap pelayanan yang di embanya. Para remaja diharapkan cakap melakukan berbagai pelayanan, mengembangan diri dalam pelayanan.

\section{METODE PENELITIAN}

Dalam penelitian ini pendekatan yang dilakukan adalah melalui pendekatan kualitatif artinya data yang dikumpulkan bukan berupa angka-angka melainkan data tersebut berasal dari angket, naskah wawancara, catatan lapangan, dookumen pribadi, catatan memo, dan dokumen resmi lainya. Sehingga yang menjadi tujuan penelitian kualititatif ini adalah ingin menggambarkan realita empirik dibalik fenomena secara mendalam, rinci dan tuntas. Oleh karena itu penggunaan pendekatan kualitatif dalam penelitian ini adalah dengan mencocokkan antara realita empirik dengan teori yang berlaku dengan menggunakan metode deskriptif. Pertimbangannya adalah, metode kualitatif lebih mudah apabila berhadapan dengan kenyataan ganda metode ini secara tidak langsung hakikat hhubungan antara peneliti dan responden metode ini lebih peka dan menyesuaikan diri dengan manajemen pengaruh bersama terhadap pola-pola nilai yang dihadapi.

Responden Penelitian ini adalah jemaat usia remaja di gereja pantekosta di Indonesia kota Palangka Raya, dengan mengambil beberapa sampel responden pengambilan responden dalam penelitian ini berjumlah 30 remaja yang berusia antara 12 (dua belas) dan 19 (Sembilan belas) tahun dari 50 remaja kemudian dijadikan unit analisis. Teknik pemilihanya dengan cara probability sampling, agar pengambilan sampel tidak keliru. ${ }^{9}$ Pemilihan sampel tidak dilakukan secara subyektif, dalam arti sampel yang terpilih tidak didasarkan pada semata-mata keinginan si peneliti sehingga setiap anggita populasi memiliki kesempatan yang sama (acak) untuk terpilih sebagai sampel. Dengan demikian diharapkan sampel yang terpilih dapat digunakan untuk menduga karakteristik populasi secara objektif. Selain itu untuk dapat menggunakan probability sampling, kita membutuhkan kerangka sampel (sampling Frame) yaitu suatu daftar dari unit-unit sampling dalam rangka untuk mendapatkan responden dengan peluang yang telah diketahui sebelumnya.

Pengumpulan data merupakan langkah yang sangat penting dalam penelitian, karena itu seorang peneliti harus tampil dalam mengumpulkan data agar mendapat data yang valid. Pengumpulan data adalah prosedur yang sistematis dan standar untuk memperoleh data yang diperlukan. Adapun pengumpulan data pada penulisan ini adalah dari data primer dan sekunder. Data primer yaitu dari sumber-sumber asli yang memuat data tersebut yaitu: pengisian angket yang akan diisi oleh para responden khususnya remaja tentang respon

\footnotetext{
${ }^{9}$ Hadari, Nawawi Metodologi penelitian bidang sosial, (Yogyakarta: Gajah mada University Press, 2003)
} 
mereka terhadap pernyataan dalam angket tersebut, berhubungan dengan frame gereja terhadap kerohanian mereka. Isi angket: dalam angket penelitian dicantumkan: usia responden ${ }^{10}$ untuk mengetahui usia/umur responden benar memenuhi kriteria penelitian remaja usia responden yang mengisi daftar kualitatif angket penelitian ditetapkan adalah dari usia 12 sampai dengan 19 tahun, ternyata dalam perolehan data dilapangan, sebaran umur sampel adalah sebagai berikut:

Tabel 1: Kategori responden berdasarkan umur

\begin{tabular}{|c|c|}
\hline Umur 13 & 2 Responden \\
\hline Umur 14 & 3 Responden \\
\hline Umur 15 & 4 Responden \\
\hline Umur 16 & 2 Responden \\
\hline Umur 17 & 5 Responden \\
\hline Umur 18 & 4 Responden \\
\hline Umur 19 & 10 Responden \\
\hline
\end{tabular}

Selain itu penelitian ini menggunakan metode observasi. Metode ini diartikan sebagai teknik pengumpulan data dengan cara mengadakan pemgamatan dan pendataan dengan sistematis tentang fenomena-fenomena yang diselidiki. ${ }^{11}$ Oleh karenanya dalam mengumpulkan data digunakan metode pengamatan dan keterlibatan langsung. Dalam pengamatan ini diusahakan mampu membaca bagaimana situasi gereja dan remaja dalam kesehariannya. Dalam keterlibatan langsung, di usahakan pula ikut berkumpul atau bergabung bersamasama para remaja setidaknya dalam ibadah remaja.

Selanjutnya metode juga dilakukan dalam pengumpulan data, dengan cara berdialog atau bertanya secara langsung dengan melibatkan gembala, beberapa remaja yang berkepentingan langsung terhadap terang gereja dalam pembinaan remaja sebagai informasi kunci. Dalam wawancara ini peneliti melakukanya bertujuan untuk mendapatkan beberapa keterangan dengan cara mengajukan beberapa pertanyaan spontan, sehingga dapat diketahui permasalahan yang terjadi. Juga peneliti akan melengkapi dengan Alkitab, buku-buku berkaitan erat dengan psikologi remaja, media online lainnya. Data tersebut dideskripsikan yang selanjutnya dianalisis sesuai dengan kaidah dan rumus yang berlaku. Proses analisis data akan dilakukan dengan langkah-langkah sebagai berikut:

${ }^{10}$ Angket tidak mensyaratkan mencantumkan nama, karena peneliti berasumsi bahwa bila responden mengisi angket tanpa mencantumkan nama, responden dapat mengisi dengan bebas sesuai dengan pendapatnya, tanpa takut diketahui identitasnya, sehingga mengurangi objektivitas pernyataan responden. Walaupun akhirnya asumsi tersebut tidak sepenuhnya benar karena ternyata, ada 10 (sepuluh) reponden yang tetap mencantumkan namanya pada angket walaupun tidak diminta.

${ }^{11}$ Sutrisno Hadi, Metodologi Research II (Yogyakarta : Yayasan Penerbit Fakultas psikologis UGM, 1990), 136. 
Menentukan jumlah skor jawaban responden dengan rumus: Total skor $\mathrm{X}$ Total Jawaban X Total Responden. Menentukan total skor ideal jawaban responden, yaitu skor yang diharapkan muncul (skor maksimal), dengan rumus: Total Teratas X Total Jawaban X Total Responden. Menentukan prosentase akhir jumlah skor responden dengan rumus sebagai berikut:

\section{$\frac{\text { Jumlah Skor Jawaban }}{\text { Skor ideal }}$ X 100\%}

Untuk membandingkan prosentase jumlah skor responden yang diperoleh dengan kriteria prosentasi skor sebagai berikut ${ }^{12}$ :

\begin{tabular}{|l|c|l|}
\hline No & Prosentasi jumlah skor & Kriteria \\
\hline 1 & $0-25$ & Sangat rendah \\
\hline 2 & $16-50$ & Rendah \\
\hline 3 & $51-70$ & Sedang \\
\hline 4 & $71-90$ & Tinggi \\
\hline 5 & $91-100$ & Sangat Tinggi \\
\hline
\end{tabular}

Data yang sudah dianalisis akan diinterpretasikan dapat diambil kesimpulannya.

Data sekunder adalah data-data yang didapat dari sumber bacaan dan berbagai macam sumber lainya yang terdiri dari surat-surat pribadi, buku harian notula rapat perkumpulan, sampai dokumen-dokumen resmi dari berbagai instansi pemerintah. Data sekunder juga dapat berupa majalah, buletin, publikasi dari berbagai oranisasi, lampiran-lampiran dari badan-badan resmi seperti kementrian-kementrian hasil-hasil studi, tesis, hasil survey, studi historis, dan sebagainya. ${ }^{13}$

Analisis deskriptif-kualitatif merupakan suatu teknik yang menggambarkan dan mengintepretasikan arti data-data yang telah terkumpul dengan memberikan perhatian dan merekam banyak mungkin aspek situasi yang diteliti pada saat itu, sehingga memperoleh gambaran secara umum dan menyeluruh tentang keadaan sebenarnya. Tujuan deskriptif ini adalah untuk membuat dekrispsi, gambaran atau lukisan secara sistematis, factual dan akurat mengenai fatka-fakta sifat-sifat serta hubunga antar fenomena yang diselidiki.

\section{HASIL DAN PEMBAHASAN}

Peneliti selanjutnya menuangkan hasil anget dalam bentuk rekapitualasi persetujuan 30 (tigapuluh) responden dalam jumlah dan prosentasi dan terdiri dari 1 (satu) angket yang dalam pendeskripsian data ini peneliti membaginya dalam 3 (tiga) angket berdasarkan kategori peran gereja dalam pembinaan kerohanian remaja pada gereja pantekosta di Indonesia kota palangkaraya dalam table hasilnya sebagai berikut:

${ }^{12}$ E.T. Ruseffendi, Dasar-dasar Penelitian Pendidikan dan Bidang Non-Ekskta Lainya (Semarang: IKIP Press, 1994), 143.

${ }^{13}$ Widodo., 56. 


\section{Ibadah}

\begin{tabular}{|c|l|c|c|c|c|}
\hline \multirow{2}{*}{ No } & \multirow{2}{*}{ Pernyataan } & \multicolumn{4}{|c|}{ Persetujuan } \\
\cline { 3 - 6 } & & \multicolumn{2}{|c|}{ Ya } & \multicolumn{2}{c|}{ Tidak } \\
\cline { 3 - 6 } & & Jumlah & \% & Jumlah & \% \\
\hline 1 & Gereja mengajarkan saya untuk pergi beribadah & 30 & 100 & 0 & 0 \\
\hline 2 & Gereja menyediakan ruangan kebaktian yang nyaman & 27 & 90 & 3 & 10 \\
\hline 3 & Gereja mengerti keperluan saya dalam hal ibadah & 28 & 93,3 & 2 & 6,7 \\
\hline 4 & $\begin{array}{l}\text { Firman Tuhan yang disampaikan menjawab permasalahn yang } \\
\text { saya alami }\end{array}$ & 26 & 86,6 & 4 & 13,4 \\
\hline 5 & Gereja sering mengadakan acara yang sesuai dengan kondisi saya & 8 & 26,6 & 22 & 73,4 \\
\hline 6 & $\begin{array}{l}\text { Gereja mengajarkan saya bahwa firman Tuhan adalah perintah } \\
\text { yang melegakan karena ketika kita mengikutinya kita akan } \\
\text { berbahagia }\end{array}$ & 24 & 80 & 6 & 20 \\
\hline 7 & $\begin{array}{l}\text { Suasana ibadah dalam ibadah kategorial di gereja saya selalu } \\
\text { menyentuh hati saya }\end{array}$ & 17 & 65,6 & 13 & 43,4 \\
\hline & Rata-rata & 22,86 & 76,19 & 7,14 & 23,81 \\
\hline
\end{tabular}

Dari tabel ini hasil rata-rata respomden yang menyatakan "ya" adalah 22,86 responden, peneliti bulatkan menjadi 23 orang, dan responden yang menyatakan "tidak" 7,14 responden peneliti bulatkan menjadi 7 orang.

\section{Persekutuan}

\begin{tabular}{|l|l|c|c|c|c|}
\hline \multirow{2}{*}{ No } & Penyataan & \multicolumn{3}{|c|}{ Persetujuan } \\
\cline { 3 - 5 } & & \multicolumn{2}{|c|}{ Ya } & \multicolumn{2}{c|}{ Tidak } \\
\cline { 4 - 6 } & & jumlah & $\%$ & jumlah & $\%$ \\
\hline 1 & $\begin{array}{l}\text { Gereja saya memberikan saya untuk bertemu dengan oang-orang } \\
\text { lain yang mengasihi Tuhan secara teratur untuk beribadah }\end{array}$ & 21 & 70 & 9 & 30 \\
\hline 2 & $\begin{array}{l}\text { Saya tahu bahwa saya dikasihi Allah dari Alkitab yang diajarkan } \\
\text { digereja }\end{array}$ & 29 & 96,6 & 1 & 3,4 \\
\hline 3 & $\begin{array}{l}\text { Saya merasa gembala/pembina/pelayan/dan teman-teman gereja } \\
\text { saya cocok untuk menjadi sahabat saya }\end{array}$ & 23 & 76,6 & 7 & 23,4 \\
\hline 4 & $\begin{array}{l}\text { Gereja mengajar kepada saya bahwa saya harus peduli pada } \\
\text { generasi saya }\end{array}$ & 23 & 76,6 & 7 & 23,4 \\
\hline 5 & $\begin{array}{l}\text { Gereja mengajarkan kepada saya, sekalipun saya muda saya dapat } \\
\text { menjadi contoh dan teladan bagi orang lain }\end{array}$ & 26 & 86,6 & 4 & 13,4 \\
\hline 6 & $\begin{array}{l}\text { Gereja sudah mengajarkan bahwa saya harus menjauhi kenakalan } \\
\text { remaja }\end{array}$ & 24 & 80 & 6 & 20 \\
\hline 7 & Gereja menghargai pendapat remaja & 23 & 76,6 & 7 & 23,4 \\
\hline 8 & Gereja mengajar karena gereja mengasihi remaja & 25 & 83,3 & 5 & 16,7 \\
\hline 9 & $\begin{array}{l}\text { Gereja dapat membantu saya menyelesaikan masalah atau konflik } \\
\text { dalam pergaulan }\end{array}$ & 20 & 66,6 & 10 & 33,4 \\
\hline 10 & Gereja disiplin tanpa menekan saya & 20 & 66,6 & 10 & 33,4 \\
\hline 11 & Gereja membantu saya untuk mengetahui potensi dalam diri saya & 22 & 73,3 & 8 & 26,7 \\
\hline 12 & Gereja membantu saya untuk mengenalsemua keterbatasan saya & 21 & 70 & 9 & 30 \\
\hline & Rata-rata & 23,08 & 76,94 & 6,92 & 23,06 \\
\hline
\end{tabular}


Dari tabel tersebut hasil rata-rata responden yang menyatakan ya adalah 23,08 peneliti bulakan menjadi 23, dan responden yang menyatakan tidak sebanyak 6,92 responden peneliti bulatkan manjadi 7 orang.

\section{Pelayanan}

\begin{tabular}{|c|c|c|c|c|c|}
\hline \multirow{3}{*}{ No } & \multirow{3}{*}{ Penyataan } & \multicolumn{4}{|c|}{ Persetujuan } \\
\hline & & \multicolumn{2}{|c|}{$\mathrm{Ya}$} & \multicolumn{2}{|c|}{ Tidak } \\
\hline & & jumlah & $\%$ & Jumlah & $\%$ \\
\hline \multirow[t]{2}{*}{1} & Gereja menyampaikan firman Tuhan yang relevan untuk remaja & & & & 16,7 \\
\hline & & 25 & 83,3 & 5 & \\
\hline 2 & $\begin{array}{l}\text { Gembala pembina/pelayana/pelayan khusus remaja digereja saya } \\
\text { adalah orang-orang yang mengerti kebutuhan remaja }\end{array}$ & 20 & 66,6 & 10 & 33,4 \\
\hline 3 & Gereja mengeajarkan saya untuk rajin disiplin rohani & 26 & 86,6 & 4 & 13,4 \\
\hline 4 & Gereja membuat saya rajin membaca Alkitab & 25 & 83,3 & 5 & 16,7 \\
\hline 5 & Saya diajarkan untuk bertanggungjawab terhadap pelayanan & 25 & 83,3 & 5 & 16,7 \\
\hline 6 & $\begin{array}{l}\text { Gereja mengajarkan untuk mengampuni seperti Yesus } \\
\text { mengampuni }\end{array}$ & 29 & 96,9 & 1 & 3,4 \\
\hline 7 & Gereja mau mendengarkan keluhan-keluhan saya & 15 & 50 & 15 & 50 \\
\hline 8 & $\begin{array}{l}\text { Keingintahuan saya tentang masalah yang menyangkut } \\
\text { seksualitas, dan perubahan saya, harus saya dapatkan dari gereja } \\
\text { saya sebagai sumber yang benar }\end{array}$ & 16 & 53,3 & 14 & 46,7 \\
\hline 9 & $\begin{array}{l}\text { Gereja mengajarkan melalui Alkitab bahwa dosa seksual } \\
\text { menyakiti hati Allah }\end{array}$ & 26 & 86,6 & 4 & 13,4 \\
\hline 10 & Gereja dapat menagtur tanpa menekan saya & 22 & 73,3 & 8 & 26,7 \\
\hline 11 & $\begin{array}{l}\text { Saya berusaha keras melakukan apa yang diajarkan firman Tuhan } \\
\text { untuk kehidupan saya sebagai remaja }\end{array}$ & 27 & 90 & 3 & 10 \\
\hline 12 & Gereja tegas tanpa menekan saya & 24 & 80 & 6 & 20 \\
\hline 13 & $\begin{array}{l}\text { Gereja membantu saya untuk mengenal kekuatan dan kelemahan } \\
\text { saya }\end{array}$ & 25 & 83,3 & 5 & 16,7 \\
\hline 14 & $\begin{array}{l}\text { Gereja membantu saya mengenal kualitas positif yang ada pada } \\
\text { saya }\end{array}$ & 26 & 86,6 & 4 & 13,4 \\
\hline 15 & Gereja membantu saya mengenal sifat negatif saya & 22 & 73,3 & 8 & 26,7 \\
\hline 16 & $\begin{array}{l}\text { Gereja mengajarkan saya untuk mengampuni teman-teman dan } \\
\text { orang lain yang menyakiti hati saya }\end{array}$ & 30 & 100 & 0 & 0 \\
\hline 17 & $\begin{array}{l}\text { Gereja mendampingi dan mendukung saya menghadap masalah } \\
\text { terbesar saya }\end{array}$ & 20 & 66,6 & 10 & 33,4 \\
\hline \multirow[t]{2}{*}{18} & $\begin{array}{l}\text { Gereja membantu saya untuk menghadapi kekuatiran saya akhir- } \\
\text { akhir ini }\end{array}$ & 21 & 70 & 9 & 30 \\
\hline & Rata-rata & 23,55 & 78,52 & 6,45 & 21,48 \\
\hline
\end{tabular}

Dari tabel ini hasil rata-rata responden yang menyatakan ya adalah 23,55 responden, peneliti bulatkan menjadi 24, dan responden yang menyatakan tidak 6,46 responden peneliti bulatkan menjadi 7 . 


\section{Analisis Data}

Untuk menentukan total skor jawaban, menentukan jumlah skor ideal dan menentukan prosentase jumlah skor responden pada pernyataan ibadah, persekutuan dan pelayanan, digunakan rumus seperti yang disebutkan pada awal penelitian ini, sehingga hasilnya didapat sebagai berukut:

\section{Ibadah}

Skor jawaban Ibadah adalah 160X 7 X $30=33.600$. Berdasarkan perhitungannya, maka diperolah perhitungan skor ideal Ibadah, yakni: 210 X 7 X $30=44.100$. Dari Rumus ini, prosentase jumlah skor responden adalah:

$$
\begin{aligned}
& \frac{33.600}{44.100} \times 100 \% \\
& =0,7619 \times 100 \% \\
& =76,19 \%
\end{aligned}
$$

Kriteria Prosentase skor ibadah prosentase skor sebesar 76,19\%, dapat disimpulkan bahwa peran gereja dalam pembinaan kerohaniaan remaja di Gereja Pantekonsta di Indonesia kota Palangka Raya dalam hal ibadah berada pada kriteria "tinggi."

\section{Persekutuan}

Skor jawaban persekutuan adalah 277 X 12 X $30=99.720$. Berdasarkan perhitungannya, maka diperoleh perhitungan skor persekutuan adalah 360 X 12 X $30=129.600$. Adapun prosentase jumlah skor responden skor responden adalah:

$$
\begin{aligned}
& \frac{99.720}{129.600} \times 100 \% \\
& =0,7694 \times 100 \% \\
& =76,94 \%
\end{aligned}
$$

Dapat disimpulkan bahwa peran gereja dalam pembinaan kerohanian remaja di Gereja Pantekosta di Indonesia kota Palangka Raya dalam hal persekutuan berada pada kriteria “tinggi" (76,94\%).

\section{Pelayanan}

Skor jawaban pelayanan adalah 424 X 18 X $30=228.960$. Berdasarkan penghitungan, maka diperoleh perhitungan skor pelayanan adalah 540 X 18 X $30=291.600$. Prosentase jumlah skor responden adalah:

$$
\begin{aligned}
& \frac{228.960}{291.600} \times 100 \% \\
= & 0,7852 \times 100 \% \\
= & 78,52 \%
\end{aligned}
$$


Dapat disimpulkan bahwa peran gereja dalam pembinaan kerohanian remaja digereja pantekosta diindonesia dikota Palangka Raya dalam hal pelayanan bearda pada kriteria "tinggi" (78,52\%).

\section{Interpretasi Data}

Setelah seluruh data tersebut dianalisis, maka dapat disimpulkan bahwa peran gereja dalam pembinaan kerohanian remaja di gereja pantekosta dikota Palangka Raya sebagai berikut: skor jawaban peran gereja dalam pembinaan kerohanian remaja gereja pantekosta di kota Palangka Raya adalah 861 X 37 X $30=955.710$. Berdasarkan penghitungan, skor peran gereja dalam pembinaan kerohaniaan remaja di Gereja Pantekosta di Indonesia kota Palangkaraya adalah 955.710. Skor ideal peran gereja dalam pembinaan kerohanian remaja gereja Pantekosta di kota Palangka Raya adalah: 1110 X 37 X $30=1.232 .100$. Presentasi jumlah skor responden adalah:

$$
\begin{aligned}
& \frac{955.710}{1.232 .100} \times 100 \% \\
= & 0,7765 \times 100 \% \\
= & 77,65 \%
\end{aligned}
$$

\section{KESIMPULAN}

Dari berbagai hasil pembahasan penelitian maka peneliti menyimpulkan bahwa peran gereja dalam pembinaan kerohanian remaja di Gereja pantekosta di Indonesia kota Palangka Raya adalah dalam kriteria tinggi dengan prosentase rata-rata 77,65\%, ini bearti bahwa gereja Pantekosta di Indonesia kota Palangkaraya telah melakukan peran pembinaan kerohanian terhadap remaja dalam hal ibadah, persekutuan dan pelayanan dengan persentasi sebagai berikut:

Pertama, terkait ibada, rata-rata 23 orang dari 30 (tiga puluh) responden atau dalam prosentase sebesar 76,19\% menyatakan persetujuanya atas pernyataan positif kualitatif bahwa ibadah sebagai bentuk pelayanan gereja yang penting terhadap remaja. Kedua, terkait persekutuan, rata-rata 23 orang dari 30 (tiga puluh) responden atau dalam persentasi sebesar 76,94\% menyatakan persetujuanya atas pernyataan kualitatif bahwa persekutuan sebagai bentuk pelayanan gereja yang positif dan penting bagi remaja untuk pergaulan dan kemampuanya bersosialisasi khususnya di lingkungan gereja. Ketiga, terkait pelayanan, rata-rata 24 orang dari 30 (tiga puluh) responden atau dalam prosentase sebesar 78,52\% menyatakan persetujuanya atas pernyataan kualitatif dan menyadari bahwa pelayanan dalam gereja adalh hal positif dan penting untuk membentuk karakter remaja.

Dengan melihat apa saja yang menjadi terang gereja dan bagaimana tanggapan positif sebagian besar responden, maka dapat disimpulkan bahwa gereja Pantekosta di Indonesia 
kota Palangka Raya telah melakukan perannya dengan baik dengan kriteria tinggi yaitu dengan prosentase rata-rata $77,65 \%$.

\section{REFERENSI}

Anthony, L. Diktat Mata Kuliah: Pelayanan Pastoral, Sekolah Tinggi Theologia Injili Indonesia, Yogyakarta

Cully, Iris V. Dinamika Pendidikan Kristen. Jakarta: BPK Gunung Mulia,1985.

Dobson, James, Menjelang Masa Remaja. Jakarta: BPK Gunung Mulia, 1986.

Hurlock, Elizabeth B. Psikologi Perkembangan, Suatu Pendekatan Sepanjang Rentang Kehidupan, Jakarta: Erlangga, 1999.

Hadi, Sutrisno. Metodologi Research, Jilid 1. Yogyakarta: ANDI OFFSET,1994.

Hadi, Sutrisno. Metodologi Research II. Yogyakarta: Yayasan Penerbit Fakultas Psikologis UGM, 1990.

Kristiono, Rahmat, "Bonus Demografi Sebagai Peluang Pelayanan Misi Gereja di Kalangan Muda-Mudi” Jurnal Teologi Berita Hidup 1 no. 2 (2019): 174-182.

Lewis, Paul. Cara Mengarahkan Anak. Bandung: Kalam Hidup, 1997.

Nawawi, Hadari. Metodologi Penelitian Bidang Sosial. Yogyakarta: UGM Press, 2003.

Sahartian, Santy, "Pengaruh Pembinaan Rohani Gereja Berdasarkan Efesus 4:17-24 Terhadap Gaya Hidup Konsumerisme Pemuda Gereja Pantekosta di Indonesia Theofilus Blitar" Jurnal Teologi Berita Hidup 1 no. 1 (2018): 31-45.

Sahartian, Santy, "Pengaruh Pembinaan Rohani Di Keluarga Terhadap Karakter Pemuda Berdasarkan Kolose 2: 6-10" Fidei: Jurnal Teologia Sistematika dan Praktika 2 no. 1 (2019): 20-39.

Singarimbun, Masri. Sofian Efendi. Metode Penelitian Survey. Jakarta: LP3S, 1985.

Setiawani, Mary GO. Menerobos Dunia Anak. Bandung: Kalam Hidup, 2000.

Tarumingkeng, Rudi. Pengantar Metode Penelitian Kuantitatif. Jakarta: Grasindo, 1999.

Tripp, Tedd, Shepperding a Child's Heart, Menggembalakan Anak Anda. Malang: Gandum Mas, 2002.

Ruseffendi, E.T. Dasar-dasar Penelitian Pendidikan dan Bidang Non-Ekskta Lainya. Semarang: IKIP Press, 1994.

Widodo, Proposal Penelitian. Jakarta: MAGNAScript Publishing, 2012. 